\title{
Pengaruh Dukungan Keluarga dalam Meningkatkan Perilaku Adaptif Remaja Pubertas
}

\author{
Endang Triyanto, Rahmi Setiyani, Rahmawati Wulansari \\ Fakultas Kedokteran dan Ilmu Kesehatan Universitas Jendral Soedirman Purwokerto \\ E-mail: endangtriyanto@yahoo.com
}

\begin{abstract}
Abstrak
Periode pubertas merupakan masa kritis bagi remaja. Perubahan akibat pubertas sering menimbulkan berbagai perilaku maladaptive seperti membolos, membangkang, dan tawuran. Keluarga sebagai lingkungan utama remaja memegang peranan penting dalam membentuk perilaku remaja. Tujuan penelitian untuk mengidentifikasi pengaruh optimalisasi dukungan keluarga terhadap perilaku adaptif pada usia pubertas. Desain quasi experimental dengan pendekatan pre-post test without control group design. Responden dipilih secara purposive sampling di Rempoah Baturaden. Perilaku adaptif remaja meningkat dari $60 \%$ menjadi $97 \%$ setelah diberikan perlakuan dukungan keluarga. Kesulitan orang tua dalam memberikan dukungan adalah ketika mengarahkan untuk belajar, menjalin komunikasi terbuka, dan menghadapi emosi remaja. Hasil penelitian menunjukkan terdapat pengaruh optimalisasi dukungan keluarga yang signifikan terhadap peningkatan perilaku adaptif remaja ( $p$ value 0.001). Orang tua hendaknya selalu meningkatkan pengetahuan untuk melaksanakan dukungan keluarga kepada anak remaja.
\end{abstract}

Kata kunci: Dukungan, keluarga, perilaku, pubertas, remaja.

\section{The effect of Family Support to Enhance the Adaptive Behavior of Adolescent}

\begin{abstract}
The period of puberty is a critical period for adolescents. The consequence of changing puberty is often arise a dis-adaptif behaviour such as a shirker, protester, gang fighter. Family as the primary environment teenager plays an important role in shaping adolescent behavior. The research objective was to identify the influence of family support for adaptive behavior of adolescent puberty. Quasi-experimental design approach without preposttest control group design was applied. Respondents was selected by purposive sampling in Baturaden. Adaptive behavior that increased from $60 \%$ to $97 \%$ after optimization family support. Difficulties of parents in providing family support when directed to learn, to establish open communication, and teenagers emotional. There is the influence of family support optimization significantly to the increase of adaptive behavior adolescents with $p$ value of 0.001 . Parents should always increase their knowledge to implement family support to teenagers.
\end{abstract}

Key words: Behavior, family, puberty, support, teenagers. 
Endang Triyanto: Pengaruh Dukungan Keluarga dalam Meningkatkan Perilaku Adaptif

\section{Pendahuluan}

Pubertas adalah suatu masa kehidupan ketika seseorang mengalami kematangan secara seksual dan organ-organ reproduksi telah siap untuk menjalankan fungsi reproduksinya (Schickedanz, 2011). Hasil penelitian yang dilakukan oleh Santrock (2008) menyimpulkan bahwa perubahan fisik pubertas yang cepat selalu disertai dengan perubahan kognitif, moral, psikologis, dan sosial. Perubahan pubertas apabila tidak diikuti kemampuan remaja untuk beradaptasi menyebabkan kemunculan beragam masalah.

Penelitian yang dilakukan oleh Allen, Insabella, dan Porter (2006) mengungkapkan perubahan kognitif remaja yang meningkat sering diwujudkan dengan rasa keingintahuan yang besar tentang berbagai hal dan akan mencari tahu dengan pemikirannya sendiri. Data tentang pornografi menunjukkan bahwa $66 \%$ anak pernah menyaksikan pornografi. Penyebab utama akses pornografi pada anak adalah rendahnya pengawasan orang tua. Rendahnya pengawasan orang tua tersebut terlihat dari lokasi akses pornografi yakni $36 \%$ di rumah, $12 \%$ di rumah teman, dan $18 \%$ di warnet.

Penelitian Triyanto(2010) mengungkapkan bahwa selain perubahan kognitif, remaja juga seringkali menunjukkan emosi yang bergejolak, sensitif, reaktif dan mudah sekali marah. Remaja pubertas ini mengalami emosi labil sebagai puncak perkembangan emosi (Wong, 2003). Penelitian yang dilakukan Evita (2012), menyatakan bahwa penyebab konflik remaja dengan orang tua maupun dengan teman sebayanya dapat menjadi penyebab kenakalan remaja. Lebih lanjut penelitian Triyanto dkk. (2011) mengungkapkan bahwa kenakalan remaja lebih disebabkan oleh keluarga yang merupakan lingkungan utama dalam membentuk perilaku.

Perubahan remaja lainnya menyebutkan bahwa pubertas dapat dikatakan sebagai kehausan sosial (social hunger) yang ditandai dengan keinginan bergaul secara berlebihan. Faktor teman juga berpengaruh terhadap remaja, apabila temannya baik maka baik pula pengaruhnya, akan tetapi apabila temannya buruk maka buruk pula pengaruhnya (Santrock, 2008). Masalah remaja yang banyak tersebut dapat menjadi bukti bahwa pubertas merupakan masa kritis. Keluarga sebagai lingkungan utama remaja memegang peranan penting yang berkewajiban memberi dukungan positif.

Penelitian yang dilakukan Triyanto (2011) menyatakan bahwa dukungan keluarga kepada remaja dalam masa pubertas di Rempoah masih tergolong rendah yaitu sebanyak $12 \%$. Lebih lanjut penelitian Triyanto (2011) menemukan bahwa banyak keluarga yang overprotective, kurang perhatian, dan merasa bingung menghadapi emosi remaja. Remaja dengan emosi yang bergejolak disertai kehausan sosial seringkali menjadi penyebab utama kebingungan orang tua dalam menghadapinya. Kebingungan orang tua dalam menghadapi remaja pubertas mengakibatkan timbulnya perilaku kenakalan remaja. Kenakalan remaja yang banyak dilakukan dapat berupa membolos sekolah, sering keluar main pada malam hari, dan sikap menentang aturan orang tua (Santrok, 2008). Menurut Kepala SMUN Baturaden, terdapat lebih dari 40 siswa yang tercatat sebagai siswa bermasalah dengan bentuk perilaku maladaptive sepanjang tahun 2012.

Puskesmas Baturaden II yang menjadi garda terdepan pusat pelayanan kesehatan masyarakat belum menjangkau kesehatan remaja dengan capaian $10 \%$ pada tahun 2012. Menurut Devi (2009) dalam studinya menemukan $50 \%$ orang tua melarang anak membicarakan seksualitas. Lebih lanjut studi Mulyadi(2008)menyimpulkan peran sekolah sebagai tempat media remaja mendapatkan informasi pubertas ternyata belum optimal. Berdasarkan fenomena tersebut maka perlu dikembangkan dukungan keluarga untuk meningkatkan perilaku adaptif remaja pubertas melalui pelatihan, pendampingan dan konseling menggunakan modul yang praktis bagi keluarga.

Optimalisasi dukungan keluarga dalam menghadapi remaja pubertas dapat dilakukan dengan menggunakan modul praktis yang mudah dimengerti oleh keluarga. Optimalisasi peran keluarga tersebut dapat dilakukan melalui pelatihan, pendampingan dan konseling dalam menghadapi anak remaja pubertas. Aktivitas ini diharapkan dapat meningkatkan pengetahuan, keterampilan dan sikap orang tua dalam menghadapi dan memberikan dukungan keluarga kepada anak remaja, sehingga remaja mampu berperilaku adaptif secara positif. Tujuan penelitian ini adalah untuk mengidentifikasi pengaruh optimalisasi dukungan keluarga terhadap peningkatan perilaku adaptif remaja. 
Endang Triyanto: Pengaruh Dukungan Keluarga dalam Meningkatkan Perilaku Adaptif

\section{Metode Penelitian}

Penelitian ini termasuk quasi experimental dengan pendekatan pre-post test without control group design. Populasi penelitian ini adalah remaja dan orang tuanya di Desa Rempoah Kecamatan Baturaden. Sampel penelitian ini adalah remaja yang memiliki masalah akademik. Sampel diambil secara purposive sampling dengan kriteria inklusi yaitu berdomisili di sekitar Desa Rempoah Kecamatan Baturaden, sehat jasmani dan rohani, dan bersedia menjadi responden. Kriteria eksklusinya adalah keluarga single parent. Jumlah sampel 30 siswa dan orang tuanya. Tempat penelitian ini dilaksanakan di Desa Rempoah Kecamatan Baturaden, Banyumas. Waktu penelitian dilakukan selama enam bulan, dimulai pada bulan Mei 2013. Instrumen penelitian yang digunakan untuk mengukur perilaku adaptif remaja pubertas menggunakan instrumen yang telah baku diambil dari Wong (2003). Komponen perilaku adaptif remaja meliputi penerimaan remaja terhadap perubahan pubertas, bergaul secara positif, dan mampu mengendalikan emosi. Wawancara dilakukan khusus untuk mengidentifikasi kesulitan orang tua dalam memberikan dukungan kepada anak remaja.

Peneliti mengambil sampel sesuai dengan kriteria inklusi penelitaan kepada 30 remaja dan kemudian meminta inform consent, selanjutnya dilakukan pretest untuk menilai perilaku remaja sebelum dilakukan perlakuan. Bentuk dukungan keluarga kepada remaja pubertas dalam penelitian ini adalah memerhatikan, memenuhi kebutuhan remaja, menjalin komunikasi terbuka, dan memberi informasi kehidupan. Keluarga diberikan pelatihan tentang pemberian dukungan keluarga terhadap remaja pubertas sebelum dilakukan intervensi. Kunjungan rumah dilakukan untuk melakukan pendampingan dan konseling keluarga kepada kedua orang tua yang dilakukan dua kali seminggu selama dua bulan. Kegiatan akhir penelitian adalah melakukan post test untuk menilai perubahan perilaku remaja pubertas setelah perlakuan. Dampak dari optimalisasi dukungan keluarga terhadap peningkatan perilaku adaptif remaja pubertas dapat diketahui dengan cara membandingkan data perilaku remaja antara sebelum dan sesudah perlakuan menggunakan uji statistik Wilcoxon.

\section{Hasil Penelitian}

Penelitian ini telah dilaksanakan sejak bulan Mei sampai Agustus 2013 di Kecamatan Baturaden Banyumas. Perilaku adaptif remaja dalam menjalani masa pubertas diukur menggunakan instrumen baku dari Wong (2003) dapat dilihat pada tabel 1.

Hasil peelitian pada Tabel 1 terlihat bahwa ada perubahan perilaku adaptif remaja secara signifikan. Sebelum perlakuan ditemukan bahwa perilaku maladaptive remaja dalam menjalani masa pubertas sebanyak 12 orang $(40 \%)$, namun setelah perlakuan turun menjadi hanya satu orang $(3 \%)$. Perilaku remaja yang termasuk kategori adaptif semakin meningkat dari 18 orang $(60 \%)$ menjadi 29 orang $(97 \%)$. Hasil penelitian tersebut menunjukkan bahwa secara statistik terdapat peningkatan perilaku adaptif remaja setelah dilakukan optimalisasi dukungan keluarga, perilaku maladaptive menjadi perilaku yang positif atau adaptif.

\section{Pembahasan}

1. Perilaku Adaptif Remaja Sebelum dan Setelah Perlakuan

Hasil penelitian ini menunjukan bahwa terjadi perubahan perilaku yang menonjol adalah pada saat remaja setelah pulang sekolah tidak langsung bermain, namun terlebih dahulu mengerjakan tugas sekolah bersama temantemannya. Mereka juga menggunakan waktu bermain sambil belajar. Remaja putri yang kini

Tabel 1 Perilaku Adaptif Remaja Sebelum dan Setelah Perlakuan di Baturaden Tahun 2013

\begin{tabular}{lcccccc}
\hline Kategori Perilaku & \multicolumn{2}{c}{$\begin{array}{c}\text { Sebelum } \\
\text { Perlakuan }\end{array}$} & \multicolumn{2}{c}{$\begin{array}{c}\text { Setelah } \\
\text { Perlakuan }\end{array}$} & Z & P Value \\
\hline & f & \% & f & \% & & 0,001 \\
\hline Maladaptive & 12 & 40 & 1 & 3 & 3,300 & \\
Adaptif & 18 & 60 & 29 & 27 & & \\
\hline
\end{tabular}


Endang Triyanto: Pengaruh Dukungan Keluarga dalam Meningkatkan Perilaku Adaptif

duduk di kelas 1 SMU Baturaden berdasarkan data instrumen yang digunakan, lebih banyak menceritakan permasalahan dengan ibunya. Remaja yang tinggal di rukun tetangga (RT) 1 rukun warga (RW) 2 Desa Rempoah Kecamatan Baturaden yang tadinya melakukan kebutkebutan di jalanan, sekarang sudah berhenti. Remaja tersebut menyadari bahwa tindakan kebut-kebutan dapat membahayakan nyawanya sendiri maupun nyawa orang lain. Berbagai perubahan positif yang paling banyak ditemukan selama penelitian menunjukkan bahwa dukungan keluarga merupakan aspek yang berperan besar terhadap perubahan perilaku remaja yang maladaptive menjadi adaptif.

Hasil penelitian ini sejalan dengan studi Triyanto (2010) yaitu saat remaja menjalani masa pubertas, mereka mulai menggunakan sebagian besar waktunya untuk bermain dan berusaha mencari teman sebanyak-banyaknya. Perilaku ini dapat menjadi maladaptive apabila teman yang dipilihnya mengarah kepada perbuatan kenakalan remaja. Penolakan teman sebaya dapat menimbulkan frustrasi dan menjadikan dia merasa rendah diri. Menurut Santrock (2008), anak tidak melihat akibat dari perilaku yang dilakukan, mereka akan melakukan hal yang menyenangkan menurut pemikirannya sendiri. Remaja akan berusaha sekuat tenaga agar dapat diterima oleh kelompoknya. Remaja yang sudah berkumpul dengan teman sebayanya seringkali tumbuh cara berpikir egosentrisme remaja yang dikenal dengan istilah personal fabel. Personal fabel ini biasanya berisi keyakinan bahwa diri seseorang adalah unik dan memiliki karekteristik khusus yang hebat, diyakini benar adanya tanpa menyadari sudut pandang orang lain dan fakta sebenarnya. Pemikiran ini berisiko terjadinya perilaku merusak diri oleh remaja yang berpikir bahwa diri mereka secara magis terlindung dari bahaya. Contoh perbuatan tersebut adalah seorang remaja pria berpikir bahwa ia tidak akan sampai meninggal dunia di jalan raya saat balapan motor.

Remaja pubertas sering menolak ketika diberikan perintah yang tidak sesuai dengan keinginan mereka. Menurut studi Triyanto (2010) pengalaman remaja selama masa pubertas mengalami perubahan sikap yaitu sikap menentang. Sikap menentang yang diungkapkan oleh dua remaja laki-laki. Bentuk penolakan yang mereka lakukan adalah jika diperintah untuk melakukan yang berkaitan dengan masa depan, misalnya belajar. Mereka biasanya juga akan menolak, apabila diperintah untuk menggunakan helm ketika hendak naik sepeda motor. Remaja akan lebih mudah mengikuti hal-hal yang menyenangkan menurut pemikiran mereka. Penelitian yang dilakukan oleh Triyanto (2010) menambahkan dalam studinya bahwa sebanyak enam remaja mengungkapkan bahwa ada perubahan emosi berupa sikap mudah marah. Bentuk emosi yang mudah marah termasuk dalam perilaku maladaptive. Setelah remaja pubertas tersebut mendapatkan perlakuan dalam penelitian ini, ditemukan penurunan emosi mengarah kepada hal positif yang ditunjukkan remaja lebih memilih atau menghindar jika mendapatkan ejekan dari teman. Remaja yang berasal dari Rempoah memilih sikap menerima ketika keinginan memiliki motor belum terpenuhi.

Kesulitan orang tua dalam memberikan dukungan kapada anak remaja yang ditemukan selama penelitian ini adalah ketika mengarahkan untuk belajar, menjalin komunikasi terbuka, dan menghadapi emosi remaja. Sejalan dengan penelitian Hurlock dan Elizabeth (2004) menyatakan bahwa selama masa pubertas, umumnya remaja memandang kehidupan sesuai dengan sudut pandangnya sendiri dan belum tentu sesuai dengan pandangan orang lain. Sikap remaja pubertas yang sering mengambil keputusan-keputusan yang bertentangan dengan norma masyarakat, akibatnya remaja pubertas tersebut sulit untuk menyesuaikan diri dengan kehidupan masyarakat yang diperlihatkan dalam sikap menentang, mereka seringkali sulit untuk diarahkan. Pemikiran yang matang tentang sikap remaja perlu dibangun keluarga sejak awal (Hurlock dan Elizabeth, 2004). Pencegahan hal-hal negatif yang dapat terjadi akibat sikap menentang remaja, oleh karena itu peran keluarga perlu memberikan pengarahan dengan cara yang lembut. Cara ini mutlak dilakukan mengingat emosi remaja juga masih labil. Keluarga wajib memberikan penjelasan kepada anak remaja bahwa setiap tindakan yang dilakukan akan membawa konsekuensi positif dan negatif. Orang tua perlu memberikan alternatif jawaban dari hal-hal yang dipertanyakan oleh putra-putri remajanya. Orang tua yang bijak sudah seharusnya memberikan lebih dari satu jawaban dan alternatif supaya remaja itu bisa berpikir lebih jauh dan memilih yang terbaik. Setelah remaja pubertas mengetahui berbagai 
Endang Triyanto: Pengaruh Dukungan Keluarga dalam Meningkatkan Perilaku Adaptif

konsekuensi yang akan terjadi dari tindakan yang akan dilakukan, harapannya adalah mereka akan berfikir kembali tentang sikap menentang yang mereka lakukan.

Remaja pubertas lebih banyak bertindak dengan menggunakan emosinya dan masih kurang dalam pemikiran rasionalitas. Pada kondisi ini, seringkali orang tua mengalami kesulitan. Hasil penelitian Triyanto (2010) dukungan keluarga yang diharapkan remaja selama menjalani masa pubertas, yaitu ingin diperhatikan, keinginan agar orang tua dapat berperan sebagai sahabat, memberikan kasih sayang, memahami, memberitahu dan dicukupi kebutuhannya. Tantangan bagi keluarga remaja pubertas adalah menyikapi perubahan emosional remaja pubertas ini dengan sikap tidak boleh terlalu keras dan juga tidak boleh diacuhkan. Bentuk perlakuan keluarga yang dilakukan secara keras pada remaja berpotensi menyebabkan terjadinya sikap remaja yang memberontak. Disisi lain, apabila perlakuan keluarga yang acuh juga akan menimbulkan perilaku negatif bagi remaja. Perhatian orang tua, kasih sayang dan pengertian orang tua dalam menghadapi sikap remaja akan membantu remaja mencapai kematangan emosi yang stabil.

Pola komunikasi yang diharapkan oleh remaja yaitu cara komunikasi yang baik, hak untuk berpendapat dan frekuensi komunikasi agar ditingkatkan. Cara komunikasi yang dimaksudkan oleh remaja pubertas adalah tidak ada pertengkaran yang berarti bahwa remaja menginginkan orang tua untuk dapat berbicara secara lembut kepada anaknya, bukan dengan membentak-bentak. Sejalan dengan penelitian Hurlock dan Elizabeth (2004) yang menyatakan bahwa bimbingan orang yang lebih tua sangat dibutuhkan oleh remaja sebagai acuan remaja dalam berperilaku. Konsistensi orang tua dalam menerapkan disiplin dan menanamkan nilainilai kepada remaja dan sejak masa kanak-kanak di dalam keluarga akan menjadi panutan bagi remaja untuk dapat mengembangkan perilaku positif. Peran orang tua tersebut diperkuat oleh studi Dian (2010) yang menyatakan bahwa perilaku ketidakpatuhan remaja pubertas disebabkan oleh tidak konsistenya pola asuh orang tua itu sendiri yang diwujudkan dalam aturan keluarga.

Orang tua yang melakukan komunikasi dua arah dengan remaja pubertas dapat mengetahui pandangan dan kerangka berpikir yang diharapkan anaknya, dan sebaliknya anak-anak dapat mengetahui hal-hal yang diinginkan orang tua. Komunikasi secara dua arah akan membantu menumbuhkan sikap saling menghargai, menerima perubahan, meningkatkan harga diri dan sikap terbuka remaja. Remaja sebaiknya diajak untuk berbicara dari hati ke hati dan dalam suasana yang santai, bahkan tidak ada salahnya apabila dalam pembicaraan tersebut sesekali diselingi dengan gurauan ringan. Suasana yang demokratis dalam rumah tangga perlu diciptakan, semua anggota keluarga bisa mengemukakan pendapatnya, tanpa harus merasa malu apalagi takut dengan anggota keluarga lainnya, terutama kepada orang tua. Hasil analisis data yang telah dilakukan Dyah (2010) diperoleh nilai korelasi antara persepsi komunikasi orang tua dan remaja dengan konsep diri sebesar 0.416 dengan $p$ value sebesar 0.000 . Persepsi penelitian pada penelitian tersebut menunjukkan bahwa terdapat hubungan yang cukup kuat antara persepsi komunikasi orang tua dan remaja dengan konsep diri pada remaja.

2. Perbedaan Perubahan Perilaku Adaptif Remaja Sebelum dan Setelah Perlakuan

Hasil penelitian ini dengan uji statistik wilcoxon diperoleh nilai $p$ value 0.001 yang berarti terdapat pengaruh optimalisasi dukungan keluarga yang signifikan terhadap peningkatan perilaku adaptif remaja pubertas. Bentuk dukungan keluarga yang dimaksud berupa dukungan material, emosional dan informasional (Friedman, 2003). Peran penting keluarga merupakan lingkungan utama dalam menyiapkan anak remaja menghadapi masa pubertas. Proses pembentukan kepribadian anak remaja tersebut dapat dilakukan dengan memberikan dukungan material, emosional dan informasi sebagai salah satu bentuk tugas perkembangan dalam keluarga. Kurangnya komunikasi, keakraban, keterbukaan dan perhatian dalam keluarga akan menganggu dalam proses pembentukan perilaku anak remaja (Gunarsa, 2005). Sejalan dengan penelitian yang dilakukan oleh Gerungan (2003) terdapat $63 \%$ remaja yang mengalami kenakalan terjadi akibat tidak berjalannya proses komunikasi antara keluarga dan remaja pubertas.

Hasil penelitian yang dilakukan oleh Herien (2003) menunjukkan bahwa pola pengasuhan mengekang akan mengakibatkan psikologi remaja menjadi tertekan, sedih, 
Endang Triyanto: Pengaruh Dukungan Keluarga dalam Meningkatkan Perilaku Adaptif

tidak percaya diri, mendendam, dan lebih cenderung melakukan pemberontakkan. Sikap pengekangan yang diungkapkan oleh remaja yang sesuai dengan pernyataan dari Soetjiningsih, Suraatmadja, dan Pangkahila (2004) bahwa seringkali orang tua terlalu overprotective kepada remaja pubertas dan tidak memberikan kesempatan untuk bergaul dengan teman-temannya. Peran keluarga terhadap remaja pubertas sangat penting sebagai wahana untuk mentransfer nilai-nilai dan sebagai agen transformasi kebudayaan (Pardede, 2002). Studi yang dilakukan Stuart (2002) menunjukkan bahwa remaja yang diberikan kesempatan bergaul dengan temannya secara bertanggung jawab lebih mampu berkomunikasi dengan baik dibanding remaja yang dikekang. Dyah (2010) menemukan bahwa apabila keluarga tidak memerhatikan kemampuan komunikasi remaja, maka dapat terjadi gangguan proses komunikasi remaja, selain itu orang tua harus memberikan pengertian yang benar tentang seksualitas.

Kemampuan remaja dalam mengambil keputusan belum didasarkan pada pemikiran yang luas. Pengawasan orang tua dilakukan dengan tujuan agar remaja tidak berperilaku yang bertentangan dengan norma masyarakat. Orang tua perlu mengingat bahwa anak remaja membutuhkan kemandirian, sehingga pengawasan yang dilakukan tidak berlebihan, misalnya ketika anak akan bermain, maka orang tua cukup untuk membuat kesepakatan waktu pulang dengan anaknya tersebut. Peran orang tua dalam memberikan kebebasan kepada anak remajanya harus diikuti dengan menanamkan rasa tanggung jawab. Setiap keputusan remaja akan membawa konsekuensi positif dan negatif. Alternatif konsekuensi yang timbul dari keputusan remaja seharusnya didiskusikan orang tua dengan anak remajanya (Stain, 2004).

Keluarga dituntut agar mampu memenuhi kebutuhan sosial remaja dalam menjalani masa pubertas yang memberikan kebebasan bergaul dengan teman sebayanya. Sikap orang tua yang tidak menganggap remaja sebagai anak kecil lagi, tetapi memberikan kebebasan untuk bergaul dapat menumbuhkan perasaan mandiri bagi remaja tersebut. Sikap demokrasi orang tua yang lainnya adalah keluarga harus mampu mengijinkan anak remajanya untuk bergaul, sehingga mereka akan mendapatkan pengalaman tentang cara-cara berkomunikasi dengan temannya. Selama proses pergaulan akan terjadi pembelajaran bagi remaja untuk berkomunikasi, apabila tahap tersebut tidak terpenuhi maka dapat terjadi gangguan pada proses komunikasi interpersonal pada remaja. Keluarga seharusnya memberikan penjelasan secara adekuat mengenai perubahan masa pubertas, permasalahan dan cara mengatasinya sejak dini kepada anak-anaknya (Weis, 2000).

Perhatian orang tua, kasih sayang dan pengertian orang tua dalam menghadapi sikap remaja akan membantu remaja mencapai kematangan emosi yang stabil. Dimasa krisis ini, orang tua harus bisa menciptakan situasi yang kondusif bagi pertumbuhan remaja seperti memberi rasa aman, menciptakan suasana yang harmonis dan ceria di rumah dan menjalin hubungan mesra dengan remaja dengan berperan sebagai sahabat. Semua faktor ini sangat menentukan keberhasilan remaja mengarungi masa-masa sulit dan krisis selama menjalani masa pubertas. Situasi yang kondusif diperlukan untuk membentuk perilaku anak (Schad, Szwedo, Antonishak, Hare, \& Allen, 2008).

Kurniadarmi (2005) bahwa bentuk dukungan material keluarga yang dapat dilakukan adalah dengan menyediakan pembalut wanita dan keperluan kecantikan, misalnya kosmetik, baju dan parfum. Bentuk dukungan material kepada anak laki-laki adalah alat komunikasi. Dukungan bagi remaja laki-laki dapat juga berupa pemberian uang saku untuk kebutuhan baju. Dilihat dari tingkat perekonomian keluarga yang sebagian masih tergolong rendah, ternyata keluarga tetap memberikan dukungan material. Berbeda dengan pernyataan Yusuf (2009) yang menyatakan bahwa rendahnya dukungan material keluarga disebabkan oleh rendahnya faktor ekonomi. Keluarga dengan tingkat ekonomi yang masih rendah, tetap menyediakan pembalut wanita. Hal tersebut tetap dilakukan keluarga, karena harga pembalut yang tidak mahal dan mudah membeli di warung-warung terdekat.

Remaja yang menjalani masa pubertas mengalami emosi yang labil, sehingga mudah marah, mudah stres dan mudah tersinggung. Keluarga mempunyai tanggung jawab dengan memberikan dukungan emosi yaitu membantu menyelesaikan permasalahan remaja dan mengatasi emosinya yang labil. Pada penelitian ini, bentuk dukungan emosional keluarga dilakukan dalam bentuk menasehati dan 
Endang Triyanto: Pengaruh Dukungan Keluarga dalam Meningkatkan Perilaku Adaptif

memahami. Menurut ungkapan remaja, kedua bentuk dukungan tersebut lebih diperankan oleh ibunya. Hal tersebut dimungkinkan pada kenyataan bahwa peran seorang ayah yang mencari nafkah untuk keluarganya, sehingga waktu yang diberikan terhadap anak-anaknya relatif lebih sedikit dibanding ibunya. Kesimpulan peneliti ini didukung oleh pernyataan Friedman (2003) bahwa peran ayah dalam keluarga adalah pencari nafkah, sedangkan peran seorang ibu lebih dominan mengasuh anak.

Remaja yang menjalani masa pubertas masih mempunyai keadaan emosi yang bergejolak. Remaja ini sangat sensitif dan akan sangat mudah tersinggung, apabila tidak cocok dengan harapan. Tantangan bagi keluarga adalah menyikapi perubahan emosional remaja pubertas ini dengan sikap tidak boleh terlalu keras dan juga tidak boleh diacuhkan. Perlakuan keluarga yang dilakukan secara keras berpotensi menyebabkan remaja yang memberontak. Di sisi lain, apabila perlakuan keluarga yang acuh akan menimbulkan perilaku negatif bagi remaja. Kenyataan inilah yang menjadi dasar pernyataan para ahli bahwa tugas perkembangan keluarga yang tersulit adalah pada tahap perkembangan remaja yang sedang menjalani masa pubertas (Pardede, 2002).

Salah satu tanggung jawab keluarga terhadap anaknya adalah membentuk perilaku anak. Remaja dalam studi kualitatif Triyanto (2011) mengungkapkan bahwa terdapat empat cara yang dilakukan keluarga dalam menegakkan aturan yaitu mengarahkan, mengingatkan, memberi contoh dan sebagian yang lain dengan paksaan. Orang tua yang menggunakan cara mengarahkan, mengingatkan dan memberi contoh merupakan cara demokratis yang memungkinkan remaja untuk menerimanya dan menjalankan aturan dengan sepenuh hati. Cara menegakkan aturan keluarga yang digunakan orang tua sangat dipengaruhi oleh karakter dan kesibukan orang tua tersebut. Remaja harus diarahkan agar mereka mampu bersikap positif dari aturan keluarga disaat orang tua melakukan pengembangan karir. Disisi lain, orang tua yang mempunyai karakter keras akan menerapkan aturan dengan sikap otoriter yaitu paksaan. Namun adakalanya, orang tua memang harus menerapkan cara paksaan, ketika remaja pubertas setelah dengan cara kooperatif tidak dapat dilakukan. Peran keluarga seperti ini menjadi sangat penting sebagai wahana untuk mentransfer nilai-nilai dan sebagai agen transformasi kebudayaan (Pardede, 2002). Sarwono (2008) menambahkan bahwa keluarga merupakan tempat menyerap nilai-nilai, norma, sikap dan bimbingan pada masa krisis yaitu masa pubertas.

Keluarga memegang peranan penting dalam pembentukan pribadi remaja dan menentukan masa depannya. Mayoritas remaja yang terlibat dalam kenakalan biasanya berasal dari keluarga yang tidak harmonis, dimana pertengkaran ayah dan ibu menjadi santapan sehari-hari remaja. Contoh persoalan dalam keluarga yang tidak harmonis adalah bapak yang otoriter, pemabuk, suka menyiksa anak, atau ibu yang acuh tak acuh, ibu yang lemah kepribadian dalam arti kata tidak tegas menghadapi remaja, kemiskinan yang membelit keluarga dan kurangnya nilai-nilai agama yang diamalkan. Kenyataan itu menjadi faktor yang mendorong remaja melakukan kenakalan (Wong, 2003). Keluarga menjadi tempat belajar remaja agar tidak menjadi pribadi yang egois. Remaja diharapkan dapat berbagi dengan anggota keluarga yang lain. Individu belajar untuk menghargai hak orang lain dan cara penyesuaian diri dengan anggota keluarga, mulai orang tua, kakak, adik, kerabat maupun pembantu.

Lingkungan, keluarga, dan individu dalam mempelajari dasar dari cara bergaul dengan orang lain yang biasanya terjadi melalui pengamatan terhadap tingkah laku dan reaksi orang lain dalam berbagai keadaan. Biasanya yang menjadi acuan adalah tokoh orang tua atau seseorang yang menjadi idolanya. Oleh karena itu, orang tua dituntut untuk mampu menunjukkan sikap-sikap yang mendukung dengan cara memberi suri tauladan. Hasil interaksi dengan keluarganya, individu juga mempelajari sejumlah adat dan kebiasaan dalam makan, minum, berpakaian, cara berjalan, berbicara, duduk dan lain sebagainya. Selain itu dalam keluarga masih banyak hal lain yang sangat berperan dalam proses pembentukan kemampuan penyesuaian diri yang sehat, seperti rasa percaya pada orang lain atau diri sendiri, pengendalian rasa ketakutan, toleransi, kerjasama, keeratan, kehangatan dan rasa aman karena semua hal tersebut akan berguna bagi masa depannya. 
Endang Triyanto: Pengaruh Dukungan Keluarga dalam Meningkatkan Perilaku Adaptif

\section{Simpulan}

Hasil penelitian ini, dapat disimpulkan bahwa terdapat pengaruh optimalisasi dukungan keluarga yang signifikan terhadap peningkatan perilaku adaptif remaja. Kesulitan orang tua dalam memberikan dukungan kapada anak remaja yang ditemukan selama penelitian ini adalah ketika mengarahkan untuk belajar, menjalin komunikasi terbuka, dan menghadapi emosi remaja. Hasil penelitian ini dapat menunjukkan bahwa orang tua yang memiliki anak remaja hendaknya selalu meningkatkan pengetahuan, keterampilan, dan sikap dalam melaksanakan dukungan kepada anak remaja.

\section{Daftar Pustaka}

Allen, J., Insabella, G. M., \& Porter, M. R. (2006). A social inter action model of the development of depressive symptoms in adolescence. Journal of Consulting and Clinical Psychology, 74 (1), 55-65.

Devi, N. (2009). Gambaran tingkat pengetahuan tentang pubertas pada siswi kelas VII di SMP Negeri 2 Sidoharjo Sragen. Jurnal Keperawatan Soedirman, 4(2), 101-112.

Dian, P. (2010). Pola asuh dalam keluarga dapat membentuk perilaku remaja: Studi kasus. Surabaya: Universitas Airlangga.

Dyah, U. (2010). Hubungan antara persepsi komunikasi orang tua-remaja dengan konsep diri remaja. Jurnal Keperawatan Soedirman, $5(1), 1-13$.

Evita, P. (2012). Studi karekteristik remaja pubertas. Jurnal Psikologi Indonesia, 6(2),7284.

Friedman, M., (2003). Keperawatan keluarga: Teori dan praktik (Edisi Ketiga). Jakarta: EGC.

Gerungan, R. (2006). A textbook of children and young people nursing. China: Churchil Livingstone Elservier.

Gunarsa, \&Singgih D. (2005). Psikologi perawatan remaja. Jakarta: BPK Gunung Mulia.
Herien, S. (2003). Hubungan pola asuh dengan psikologis remaja (Tesis Universitas Gadjah Mada, Yogyakarta).

Hurlock, \& Elizabeth B., (2004). Psikologi perkembangan suatu pendekatan sepanjang rentang kehidupan manusia. Yogyakarta: Erlangga.

Kurniadarmi, E. (2005). Perilaku agresif pada anak usia sekolah dan remaja awal : Studi kualitatif. Mandala, 1(2),112-124.

Mulyadi, B. (2008). Pengalaman anak jalanan laki- laki dalam menjalani masa puber di Pancoranmas Kota Depok: Studi fenomenologi. (Tesis). Universitas Indonesia, Depok.

Pardede, N. (2002). Tumbuh kembang anak dan remaja. Jakarta : Sagung Seto.

Santrock, J. W. (2008). Perkembangan remaja. Jakarta: Erlangga.

Sarwono, S. W. (2008). Survey perilaku remaja di Baturaden Purwokerto. Jurnal Keperawatan Soedirman, 3(2), 112-118.

Schad, M. M., Szwedo, D. E., Antonishak, J., Hare, A., \& Allen, J. P. (2008). The broader context of relational aggression in adolescent romantic relationships: Predictions from peer pressure and links to psychosocial functioning. Journal of Youth and Adolescence, 3 (3), 346358.

Schickedanz, J. A. (2011). Understanding children and adolescences. Boston: Allyn and Bacon.

Soetjiningsih, R., Suraatmaja, R., \& Pangkahila, F. (2004). Buku ajar tumbuh kembang remaja dan permasalahannya. Jakarta: Sagung Seto.

Stain, S. (2004). Adolescent girls perspective of family interactions related to menarche and sexual health. Michigan State University Collage of Nursing, East Lansing Qualitative Health Research,4(2), 192-204.

Stuart, S. (2002). Adolescent health and development. Journal of Adolescent, 2(1), 191205. 
Endang Triyanto: Pengaruh Dukungan Keluarga dalam Meningkatkan Perilaku Adaptif

Triyanto, E. (2010). Pengalaman remaja menjalani masa pubertas : Studi fenomenologi. Jurnal Ners, 5(2), 181-195.

Triyanto, E. (2011). Dukungan keluarga yang diperlukan remaja selama menjalani masa pubertas. Jurnal Keperawatan Soedirman, 6(2), 122-137.

Weis, M. (2000). Risk and protective factors affecting adolescent reproductive health in developing countries. Journal of Teenagers, 2(2), 276-289.

Wong, A. (2003). Nursing care of infants and children. Canada: Mosby Elsevier.

Yusuf, Syamsul. (2009). Psikologi perkembangan anak \& remaja. Bandung: PT Remaja Rosda Karya. 